\title{
Electrical Conductivity Structure of Southeastern North America: Implications for Lithospheric Architecture and Appalachian Topographic Rejuvenation
}

\author{
Benjamin S. Murphy, Gary D. Egbert
}

Keywords: Appalachians, Appalachian Orogen, Central Atlantic Magmatic Province, Topographic Rejuvenation, Magnetotellurics

\begin{abstract}
We present the first three-dimensional view of the lithospheric electrical conductivity structure beneath southeastern North America. By inverting EarthScope long-period magnetotelluric (MT) data, we obtain an electrical conductivity image that provides new insights into both the architecture of the Appalachian Orogen and the cryptic post-rifting geodynamic history of the southeastern United States. Our inverse solutions reveal several elongate electrically conductive features that we interpret as major terrane sutures within the Appalachian Orogen. Most significantly, we resolve a highly electrically resistive layer that extends to mantle depths beneath the modern Piedmont and Coastal Plain physiographic provinces. As high resistivity values in mantle minerals require cold mantle temperatures, the MT data indicate that the sub-Piedmont thermal lithosphere must extend to greater than $200 \mathrm{~km}$ depth. This firm bound conflicts with conclusions from seismic results. The boundary between the anomalously thick, resistive sub-Piedmont lithosphere and the relatively thin, moderately conductive subAppalachian lithosphere corresponds within resolution to the modern Appalachian topographic
\end{abstract}


escarpment. This newly recognized contrast in lithospheric properties likely has important

24 implications for Appalachian topographic rejuvenation.

\section{Introduction}

Beneath the dense vegetation and the thick accumulations of saprolite, the crust and mantle lithosphere of the southeastern United States (Fig. 1) record a complicated history of accretionary and collisional orogenies, continental rifting, and passive-margin evolution. Although often scientifically overshadowed by the more active west, the eastern margin of North

31 America nevertheless provides a natural laboratory for studying cryptic geodynamic and tectonic problems. The recent acquisition of EarthScope seismic and magnetotelluric (MT) data on the east coast of the United States now permits unprecedented three-dimensional views of the lithosphere beneath this enigmatic region.

The past and present evolution of the Appalachian Orogen dominates the geologic heritage of eastern North America. The ancestral Appalachian mountains were the product of a full Wilson cycle that spanned the late Mesoproterozoic to the late Paleozoic (Hatcher, 2010). The Grenville Orogeny at $\sim 1.1 \mathrm{Ga}$ marked the assembly of Rodinia, which persisted in various forms into the Neoproterozoic. Following Iapetan rifting of this supercontinent in the latest Neoproterozoic to early Cambrian, a series of Paleozoic terrane-suturing events in eastern Laurentia culminated in 1 the Alleghenian Orogeny, which marked the assembly of Pangea and the closure of the Rheic Ocean. In the southern Appalachian Orogen, two pre-Pangean accretionary events are generally recognized: the mid-Ordovician Taconic Orogeny and the late-Ordovician to Silurian Cherokee Orogeny, in which the Carolina Superterrane (Carolina Zone) docked onto Laurentia (Hibbard et al., 2010; Fig. 1). In the mid-Mesozoic, Pangea was rifted apart with the opening of the Atlantic 
Ocean. During this time, at 200 Ma, the Central Atlantic Magmatic Province (CAMP; e.g.,

47 Whalen et al., 2015) formed as the largest continental large igneous province so far recognized in

48 the geologic record. Geochemical evidence indicates that a mantle plume did not generate

49 CAMP; rather, these flood basalts are likely due to passive continental rifting associated with

50 orogenic collapse (Whalen et al., 2015; Frizon de Lamotte et al., 2015). With growth of the

51 Atlantic Ocean, eastern Laurentia became a passive margin. The region has experienced no

52 major tectonism since the mid Mesozoic.

Multiple lines of evidence suggest that the modern Appalachians Mountains are the result of

54 topographic rejuvenation that occurred after the ancestral Alleghenian highlands had been eroded away. Geomorphic evidence indicates that the topography of the Southern and Central Appalachians is not in equilibrium (Gallen et al., 2013; Miller et al., 2013; Prince and Spotila, 2013). Apatite (U-Th)/He thermochronology suggests that topographic relief increased in the Southern Appalachians in the late Cretaceous (McKeon et al., 2014). Most importantly, the

59 Cenozoic stratigraphic record on the Atlantic shelf shows major pulses of sedimentation in the 60 Cretaceous and the Miocene that likely represent periods of topographic rejuvenation (Poag and 61 Sevon, 1989). Multiple mantle-driven mechanisms for such low-magnitude topographic 62 disequilibrium and rejuvenation have been proposed, including both dynamic subsidence and 63 dynamic uplift due to large-scale mantle flow (Moucha et al., 2008; Spasojević et al., 2008; Liu, 2014) and hydration of the mantle beneath eastern Laurentia due to dewatering of the deep Farallon slab (van der Lee et al., 2008). Surficial processes, such as stream capture and basin reorganization (e.g., Willet et al., 2014), have also been suggested as an explanation for topographic disequilibrium. Despite much work on the history and development of modern

8 Appalachian topography, no single explanation has yet to be widely accepted. 
$70 \quad$ United States (Fig. 1) to provide a new geophysical perspective on the geologic architecture and 71 geodynamic evolution of this region. Our work expands significantly on previous two-

72 dimensional MT studies of the Appalachian Orogen (Ogawa et al., 1996; Wannamaker, 2005),

73 which imaged several of the features we observe here but which could not thoroughly explore 74 the implications of those features due to the limitations of their data. With the EarthScope MT dataset, we are now able to better constrain and interpret lithospheric electrical structures.

\section{Data and Methods}

Our dataset comprises full MT impedance tensors and vertical magnetic field transfer functions in the period range of $\sim 10 \mathrm{~s}$ to $\sim 10,000 \mathrm{~s}$ from 124 EarthScope Transportable Array

1 community use through IRIS (http://ds.iris.edu/spud/emtf). We prescribed error floors of 5\% for

2 impedance tensor components (treating the two rows separately) and 0.03 for the real and

imaginary parts of the vertical magnetic field transfer function components. We inverted the data

with ModEM, a three-dimensional isotropic electromagnetic inversion code (Kelbert et al.,

2014). Nominal horizontal grid-cell size for our model domain is $12 \mathrm{~km}$. Vertical grid-cell size

6 telescopes logarithmically to a maximum model depth of $900 \mathrm{~km}$. Cell thickness is $\sim 200 \mathrm{~m}$ at the

surface; vertical grid-cell size is $\sim 50 \mathrm{~km}$ at $300 \mathrm{~km}$ depth. Because the typical site spacing is $\sim 70$

$8 \mathrm{~km}$ and the shortest period in our dataset is $\sim 10 \mathrm{~s}$, our model parameterization is sufficiently fine

to model crust- and lithosphere-scale structures as well as the effects of distortion. We used a

nested inversion approach to account for possible effects of large-scale electrical structures

91 beyond our data footprint. The larger model within which our inversions were embedded was 
92 derived from a coarse-scale inversion of all available EarthScope MT data in the eastern half of

93 the United States. This large model included both the Atlantic Ocean and the Gulf of Mexico.

94 We assess gross model resolution through multiple inversion runs that utilized a range of

95 prior resistivity models and that had various constraints imposed. Note that, in the ModEM

96 regularization approach, deviations from a prior model are penalized (Kelbert et al., 2014);

97 therefore, only features that appear for a range of prior models are considered required by the

98 data. Results from an illustrative selection of inversion runs are shown in the Supplementary

99 Materials. For the preferred solution shown here, a ModEM smoothing setting of 0.2 with two

100 passes was utilized. In the inversion code, model smoothing is part of the inversion

101 regularization. For our model discretization and covariance settings, features are smoothed over a

102 length scale of $\sim 30 \mathrm{~km}$. This spreads bulk resistivity values into adjacent cells to the extent that

103 regional-scale features are easily identified while also providing reasonable localization of those

104 features. The preferred inversion began with a prior half-space resistivity of $180 \Omega \mathrm{m}$ that

105 included ocean cells frozen to $0.3 \Omega \mathrm{m}$. A normalized root-mean-square misfit of 1.75 was

106 achieved after 350 iterations of the ModEM inversion. Further discussion of the data fit as well

107 as resolution tests are presented in the Supplementary Materials.

108

109 3. Results

110 Our preferred inverse solution is shown in Figure 2. We identify five well-resolved

111 electrically conductive structures, denoted C1 through C5; three poorly resolved but significant

112 electrically conductive features, identified EC1 through EC3; and two zones of high resistivity,

113 denoted R1 and R2 (Fig. 2). The features presented here are those that we currently consider 
114 robust in at least some capacity based upon multiple inversions and resolution tests (see 115 Supplementary Materials).

116 Structures C1, C2, and C3 are major Appalachian-parallel, mid- to lower-crustal conductors. 117 These three structures follow the northeast-southwest, slightly sinuous grain of the Appalachian 118 Orogen. The average vertically integrated conductances ( 25-50 km depth) are $3300 \mathrm{~S}$ for C1, $1192800 \mathrm{~S}$ for $\mathrm{C} 2$, and $1500 \mathrm{~S}$ for C3. (Average conductances are calculated for the spatial footprint 120 of each conductor as defined in Figure 2.) The signature of highly conductive structure $\mathrm{C} 1$ is 121 apparent in the vertical magnetic field transfer functions. These data are plotted in Figure 3 as 122 induction vectors (e.g., González-Castillo et al., 2015), which (with the Parkinson sign 123 convention used here) point to anomalous conductors. C1 was observed in a previous two124 dimensional MT study of the Appalachian Orogen (Wannamaker, 2005). C4 is a weak, east-west 125 trending conductive feature in the mid to lower crust of central Georgia. Its average vertically 126 integrated conductance ( $25-50 \mathrm{~km}$ depth) is $210 \mathrm{~S}$; this is marginally greater than a conductance 127 of $190 \mathrm{~S}$ for the same region of the prior model. Although the conductivity contrast with the 128 surrounding model domain is minimal, this structure appears in all inverse solutions and is 129 therefore considered to represent a real feature. Structure C5 is a robust conductor in the mid to 130 lower crust of central South Carolina that, at least at mid-crustal depths, weakly connects 131 southwestward to C4 and the southernmost extent of C3.

132 Anomalies EC1, EC2, and EC3 appear consistently in inversions (Figs. S10-S12) beyond the 133 footprint of our dataset. Although the exact positions and geometries of these structures are not 134 resolved due to present limits on data coverage, their persistence in inversions suggests that they 135 do represent real electrically conductive features outside of the current array. EC1 appears 136 offshore of the study region, beneath the continental shelf; EC2 is imaged in southeastern 
137 Alabama along the border with Georgia; and EC3 lies to the north of the array along the West

138 Virginia-Virginia border. Induction vectors (Fig. 3) point to EC2 and EC3 and are therefore

139 consistent with the high conductivities observed in the inverse solutions in these areas.

140 Perhaps the most enigmatic feature that appears in all inverse solutions is the large, thick

141 block of resistive material beneath the Piedmont and Coastal Plain physiographic regions (Figs.

142 1,2). We refer to this structure, which was observed in a previous two-dimensional MT study of

143 the region (Wannamaker, 2005), as R1. In the preferred inverse solution (Fig. 2), high resistivity

144 values associated with this structure extend to depths greater than $300 \mathrm{~km}$. Resolution tests (see

145 Supplementary Materials) indicate that this feature must maintain bulk resistivity values of at

146 least $1000 \Omega \mathrm{m}$ to a depth of at least $200 \mathrm{~km}$.

147 Strikingly, the northwestern limit of structure R1 coincides with the modern Appalachian

148 topographic escarpment (Figs. 1, 2; see also Figs. S6-S7 for resolution tests). At $200 \mathrm{~km}$ depth,

149 the region to the northwest of the escarpment displays resistivity values on the order of $100 \Omega \mathrm{m}$,

150 whereas the region to the southeast displays resistivity values higher than $1000 \Omega \mathrm{m}$ in

151 association with structure R1 (see Figs. S8-S9 for resolution tests). This sharp boundary in deep

152 resistivity is clearly evident in plots of apparent resistivity and phase in an Appalachian-parallel

153 coordinate system (Figs. S13, S14). Therefore, both multiple inversions and the data themselves

154 indicate the presence of a major conductivity contrast between the mantle beneath the modern

155 Appalachian highlands and the mantle beneath the Piedmont and Coastal Plain.

156 Finally, structure R2 is a small Appalachian-parallel resistive feature that appears in the

157 lowermost crust and uppermost mantle beneath western North Carolina. This structure exhibits

158 resistivity values up to $1000 \Omega \mathrm{m}$ and is separated from structure $\mathrm{R} 1$ by a zone of moderate

159 electrical conductivity that extends downward from structure C3. 


\section{4. Discussion}

\subsection{Well-Resolved Shallow Structures}

163 Structures C1, C2, C3, C4, and C5 are spatially coincident with terrane sutures inferred from

164 studies of surface geology. As sutures have frequently been associated with elongate crustal

165 conductors (e.g., Boerner et al., 1996; Jones et al., 2005; Wannamaker, 2005; Yang et al., 2015),

166 we interpret these conductive structures as representing the major terrane sutures of the Southern

167 Appalachian Orogen. The high conductivities associated with these structures are likely due to

168 graphitic or authigenic-sulfide-rich sediments that became trapped in these zones of crustal

169 convergence (e.g., Boerner et al., 1996; Wannamaker, 2005). We interpret C1 to represent the

170 main Grenville suture; C2, the Taconic suture; and C3, the main Carolina Superterrane suture.

171 We interpret C4 and C5 to be associated with the Suwannee terrane.

172 Structure C1 coincides with the New York-Alabama (NY-AL) Lineament (Fig. 3), a

173 continent-scale aeromagnetic anomaly (e.g., Steltenpohl et al., 2010) that, based upon regional

174 contrasts in radiogenic isotope affinities, has been interpreted to represent the main Grenville

175 suture (Fisher et al., 2010). Our electrical resistivity images therefore provide strong geophysical

176 support for this geologically motivated interpretation. Both the induction vectors (Fig. 3) and

177 inverse solutions indicate that structure $\mathrm{C} 1$ is highly conductive, more so than any other feature

178 in the model. Repeated reactivation of the corresponding fault system to accommodate both

179 orogen-perpendicular and orogen-parallel deformation throughout the latest Neoproterozoic and

180 the Paleozoic (Steltenpohl et al., 2010) likely helped to concentrate and connect conductive

181 phases and thereby increase bulk conductivity over time (e.g., Wannamaker, 2005). 

trend (Fig. 1; Boote and Knapp, 2016; Hopper et al., 2017; cf. Hatcher, 2010). Therefore, C5 may be part of the reinterpreted Suwannee suture and C4 may be a suture within the larger Suwannee terrane. (The downward continuation of C5 into the mantle shown in the preferred inverse solution is not robust; cf. Figs. S10-S12.) However, whereas seismic receiver function images indicate that the Suwannee suture dips shallowly through the crust, C5 appears at mid- to lower-crustal depths almost directly beneath the inferred surface trace of the redefined Suwannee suture. Resolution tests indicate that depth is poorly constrained for at least the weak southwestern extension of structure C5 (Figs. S10-S12), so this discrepancy may be due to the poor upper-crustal resolution of these long-period MT data. Curiously, the footprint of C5 is spatially coincident with an isolated relative isostatic gravity low (Figs. 2, 4). Structure C5 may therefore hold additional significance beyond representing a terrane suture. Further analysis is needed to explore the nature of this structure, especially as its relationship with $\mathrm{C} 3$ and $\mathrm{C} 4$ is complex. Incorporation of broadband MT data would greatly clarify these crustal-scale structures.

These conductive features (at least C1, C2, and C3) define lateral limits on the extent of rocks of different terrane affinities in the mid to lower crust. In particular, our results indicate that Grenvillian rocks do not extend southeastward in the lower crust beneath the Piedmont and Coastal Plain, as has been suggested previously (e.g., Cook and Vasudevan, 2006). Furthermore, the interpreted mid- to lower-crustal electrical expressions of the Grenville, Taconic, and Carolina sutures lie almost directly beneath their surface expressions. Therefore, based on the MT images presented here, these sutures appear to extend essentially continuously through the entire crust in the Southern Appalachian Orogen. This structural model stands in contrast to that 

upper-crustal expression of these sutures to be significantly offset $(\sim 400 \mathrm{~km})$ to the northwest north of the (redefined) Suwannee suture; because compelling seismic images indicate that the Suwannee suture is a low-angle detachment (Hopper et al., 2017), crustal architecture is likely far more complicated at the southernmost end of the orogen. Further detailed exploration of the geologic implications of these structures is left for future study. lithospheric discontinuity that was detected by receiver-function imaging (Wagner et al., 2012). Previous studies have interpreted this seismic structure as a dangling remnant of either the Iapetan slab from accretion of the Carolina Superterrane (Wagner et al., 2012) or the Rheic slab after closure of the ocean between Laurentia and Gondwana (Whalen et al., 2015). However, because Carolinian subduction is believed to have been directed westward (Hibbard et al. 2010), neither of these previous explanations seems geometrically consistent with our resistivity images, which show structure R2 to the northwest of the downward continuation of what we interpret to be the Carolina Superterrane suture (C3). Alternatively, this feature could be a dangling remnant of the Iapetan slab that was trapped during the Taconic Orogeny. However, this interpretation is also geometrically problematic, as Taconic subduction is believed to have been directed to the east (e.g., Abbott and Greenwood, 2001) and structure R2 appears to the southeast of the conductive signature of the Taconic suture (C2). This structure therefore remains enigmatic.

\subsection{Poorly Resolved Structures}


The high bulk conductivity values associated with EC1 in the preferred inverse solution (Fig. 2) do not appear in all solutions (cf. Figs. S10-S12). This feature is likely an edge effect due to conductive shelf sediments or some other unresolved offshore, crustal-scale conductive structure. Such a conductor could correspond to the Alleghenian suture, which would mark the Laurentian boundary along which Pangea was assembled. However, EC1 appears in inversions southeast of the Suwannee suture, which is the Alleghenian suture in the southernmost Appalachian orogen (e.g., Boote and Knapp, 2016). This unresolved conductor could alternatively represent a structure within the Suwannee terrane.

The coherent, large amplitude, southwest-pointing induction vectors that cover most of 236 Georgia and South Carolina (Fig. 3) require the presence of a major electrical conductivity 237 contrast in the crust or upper mantle beneath southern Alabama or the northernmost Gulf of 238 Mexico. Such a structure is represented in inverse solutions as EC2, although the characteristics 239 of this feature are unresolved. Recent surface-wave tomography (Pollitz and Mooney, 2016) 240 shows an isolated slow seismic anomaly in southern Alabama that may be due to lithospheric 241 modification associated with passage of the Bermuda hotspot track underneath southern

242 Laurentia at the end of the Cretaceous (Cox and Van Arsdale, 2002). Plume impingement could 243 increase lithospheric conductivity by introducing water or even mantle sulfides into the 244 constituent mantle rocks. However, slow shear-wave velocities in southern Georgia (Pollitz and 245 Mooney, 2016) that may also be associated with this hot-spot track spatially coincide with 246 resistive structure R1 in our inverse solutions, which possibly conflicts with what would be 247 expected if hot-spot refertilization had significantly altered the lithosphere in this region. Alternatively, the thick sediment package in the Gulf of Mexico or the edge of resistive structure 249 R1 could be responsible for the pattern in the induction vectors and for the appearance of EC2 in 
250 inverse solutions. Forward-modeling tests suggest that either enhanced mantle conductivity or a

251 sharp southwestern edge on R1 may explain the induction vectors (Fig. S15); however, further

252 expansion of the EarthScope MT dataset into Alabama will be necessary to resolve the

253 lithospheric electrical conductivity structure of this area.

254 Structure EC3 coincides with a region of Eocene volcanism that hosts the youngest volcanic

255 rocks found on the eastern margin of the United States (e.g., Mazza et al., 2014). This volcanism

256 has been ascribed to asthenospheric upwelling associated with a delamination event (Mazza et

257 al., 2014), although hotspot activity is an equally compelling explanation (Chu et al., 2013). As

258 EC3 lies at the edge of our current data footprint, at present our data cannot clearly distinguish

259 between these two competing hypotheses.

260

4.3 Deep Lithospheric Conductivity Contrast and the Piedmont Resistor

We interpret resistive structure R1 as representing thick sub-Piedmont lithosphere. In the

263 discussion that follows, we rely on the thermal definition of the lithosphere: the thickness of

264 mantle and crustal material that lies above the $\sim 1300^{\circ} \mathrm{C}$ isotherm.

265

4.3.1 Constraints from the Magnetotelluric Data: Thick Sub-Piedmont Lithosphere

267 In our preferred inverse solution, the lithosphere beneath the modern Appalachian highlands

268 displays resistivity values of $\sim 100-300 \Omega \mathrm{m}$, which can be explained by moderate hydration $(\sim 10-$

269100 ppm $\mathrm{H}_{2} \mathrm{O}$, Fig. 5; Selway, 2014; Gardés et al., 2014) at lower-lithosphere temperatures of

$270 \sim 1000^{\circ}-1200^{\circ} \mathrm{C}$. The moderately conductive lithosphere beneath the modern Appalachian

271 highlands only extends to depths of $\sim 150-200 \mathrm{~km}$, as typical asthenospheric conductivity values

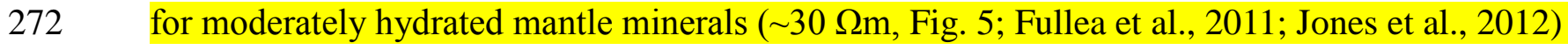


appear in the inverse solution by a depth of $200 \mathrm{~km}$ in this region. Although mantle minerals could display resistivity values of $\sim 30 \Omega \mathrm{m}$ at lithospheric temperatures with more than $\sim 500 \mathrm{ppm}$ incorporated $\mathrm{H}_{2} \mathrm{O}$ (Gardés et al., 2014), such water contents would be at or above the solubility limit at pressures corresponding to $200 \mathrm{~km}$ depth ( $6 \mathrm{GPa}$; Ardia et al., 2012). Additionally, if Appalachian lithosphere were to extend to $\sim 250-300 \mathrm{~km}$ depth, temperatures at $\sim 100 \mathrm{~km}$ would be $\sim 600^{\circ} \mathrm{C}$ for a reasonable conductive geotherm and the uppermost mantle lithosphere would then need to be hydrated with $>1000 \mathrm{ppm} \mathrm{H}_{2} \mathrm{O}$ in order to produce resistivity values of $\sim 100 \Omega \mathrm{m}$ (Fig. 5; Yoshino et al., 2009; Jones et al., 2012; Dai and Karato, 2014; Gardés et al., 2014). Such

281 levels of hydration are unrealistic (Keppler and Bolfan-Casanova, 2006). Based on these considerations, the MT data suggest that the modern Appalachian thermal lithosphere is no more than $\sim 150-200 \mathrm{~km}$ thick.

In contrast, the lithosphere beneath the Piedmont and Coastal Plain (R1) must extend to depths greater than $200 \mathrm{~km}$ and must be minimally hydrated. For all volumetrically significant mantle minerals (those that will dominantly control electrical conductivity), the maximum resistivity that could possibly be observed at $1300^{\circ} \mathrm{C}$ (the approximate temperature at the $\mathrm{LAB}$ ) under dry conditions is $\sim 300 \Omega \mathrm{m}$ (Fig. 5; Constable, 2006; Fullea et al., 2011; Jones et al., 2012; Selway, 2014). Even small amounts of incorporated water $\left(\sim 10 \mathrm{ppm} \mathrm{H}_{2} \mathrm{O}\right)$ will lower the maximum possible temperature (Fig. 5). Therefore, the resistivity of dry mantle minerals provides an upper limit on temperature as well as a lower limit on sub-Piedmont thermal 292 lithospheric thickness. As the data require resistivity values of $\sim 1000 \Omega \mathrm{m}$ to a depth of at least $293200 \mathrm{~km}$, temperatures at that depth must be $\leq 1200^{\circ} \mathrm{C}$ and the LAB beneath the Piedmont must 294 therefore lie deeper than $200 \mathrm{~km}$. 
As electrical conductivity of dry mantle minerals is controlled primarily by temperature alone

296 (Constable, 2006; Fullea et al., 2011), this conclusion is robust. At lithospheric temperatures and

297 in the absence of interstitial water, thermally activated small-polaron hopping, which amounts to

298 valence swapping between $\mathrm{Fe}^{2+}$ and $\mathrm{Fe}^{3+}$ within the crystal lattice (Elliot, 1998), is the dominant

299 conduction mechanism in olivine, orthopyroxene, and clinopyroxene (e.g., Selway, 2014).

300 Although this mechanism is dependent on iron content and oxygen fugacity to a limited extent

301 (these control the number of charge carriers), temperature (which controls carrier mobility) is the

302 overwhelmingly dominant factor that determines electrical conductivity (Fig. 5; Constable, 2006;

303 Fullea et al., 2011). Since dry mantle minerals display minimal electrical anisotropy (e.g., Du

304 Frane et al., 2005), this conclusion does not depend on mantle fabric. As electrical conduction in

305 dry mantle silicates is well studied and understood in terms of both laboratory results (e.g.,

306 Constable 2006) and solid-state physics theory in general (e.g., Elliot, 1998), our bound on sub-

307 Piedmont lithospheric temperature and, by extension, thermal lithospheric thickness rests on a

308 solid foundation.

309 Our data thus strongly suggest the presence of a step in the LAB between the modern

310 Appalachian highlands and the Piedmont. This coastward increase in LAB depth is

311 geoelectrically characterized by a contrast between lithospheric resistivity values typical of

312 Phanerozoic lithosphere and anomalously high lithospheric resistivity values.

\subsubsection{Comparison to Seismic Images: Minor Agreement and Major Conflict}

315 Our observation of a slightly hydrated lithosphere beneath the modern Southern Appalachian 316 topographic highs is compatible with results from a study of local Pn travel times that indicate 317 uppermost-mantle hydration in this region (MacDougall et al., 2015). Our depth range for the 

thickness from body- and surface-wave tomography (Biryol et al., 2016; Pollitz and Mooney, 2016). However, the thick sub-Piedmont lithosphere that we observe with the MT data stands in conflict with images derived from body- and surface-wave tomography (Schmandt and Lin, 2014; Biryol et al., 2016; Pollitz and Mooney, 2016). Mantle lithosphere that extends beyond 200 km depth would follow an anomalously cold conductive geotherm and would therefore be expected to be clearly visible in body-wave travel times as a well-defined fast anomaly. However, no such anomaly is observed in seismic travel-time datasets or in body-wave tomography inversions (Schmandt and Lin, 2014; Biryol et al., 2016). Continent-scale bodywave tomography (Schmandt and Lin, 2014) shows that mantle velocities in this region deviate very little from the reference model. Local compressional body wave tomography (Biryol et al., 330 deviations $(<1 \%)$ from the reference model, although more significant slow-velocity anomalies 331 (up to $\sim 3 \%$ ) are also detected beneath the Piedmont and Coastal Plain. While local surface-wave 332 inversions (Pollitz and Mooney, 2016) do not image an anomalous feature that could correspond 333 to this large lithospheric resistor, more recent continent-scale surface-wave work (Shen and 334 Ritzwoller, 2016) does appear to show relatively high shear-wave velocities beneath the 335 Piedmont and Coastal Plain and lower shear-wave velocities beneath the adjacent Appalachians. 336 Shear-wave splitting measurements show a contrast in behavior between the two lithospheric 337 domains that we image here, although this pattern could be the result of overprinting by shallow 338 lithosphere structures, such as sutures (Long et al., 2016). Measurements of local Pn travel times 339 do indicate higher compressional-wave velocities beneath the Piedmont than beneath the modern 
341 shallowest mantle (Biryol et al., 2016).

342 It is difficult, but not impossible, to reconcile the seismic and the MT results. While

343 temperature is the first-order control on seismic velocity in the upper mantle, the effects of

344 lithology or composition may be more important in defining anomalies than is widely

345 appreciated. For example, an increase in the iron content of mantle rocks and a decrease in

346 ambient temperature have opposite effects on seismic velocities (Cammarano et al., 2003; Lee,

347 2003). That is, a decrease in magnesium number by $4-5$ units can offset effects of decreasing

348 temperature by $100-200^{\circ} \mathrm{C}$ on seismic velocities so that the net deviation from a reference model

349 is roughly zero. Changes in mineralogy can also affect seismic velocities. For example, a

350 decrease in olivine content from $100 \%$ to $60 \%$ will decrease $V_{P}$ by $\sim 1 \%$ (Lee, 2003), and

351 enrichment in orthopyroxene (up to $\sim 50 \%$ ) in particular can further lower $V_{P}$ by up to $1 \%$ (Schutt

352 and Lesher, 2010). Furthermore, mantle pyroxenite can be invisible to body-wave tomography,

353 as under certain circumstances cold pyroxenite may exhibit similar seismic velocities to fertile

354 asthenospheric (i.e., hot) peridotite (Erdman et al., 2016, their Fig. 3). As the MT data lead to the

355 seemingly inescapable conclusion that sub-Piedmont mantle temperatures are colder than would

356 be expected, careful consideration of possible compositional effects on seismic velocity is

357 warranted.

\subsubsection{Possible Explanation: A Metasomatized Lithospheric Root that Regrew after Delamination}

361 the generation of CAMP lavas (Whalen et al., 2015). If the resulting void in the mantle

362 lithosphere were filled by material that formed from asthenospheric consumption of the 
363 delaminant or that trapped significant volumes of partial melt, then the regrown, now-cold

364 lithospheric root could plausibly be electrically resistive but not particularly seismically

365 anomalous.

366 The model that we propose here is shown graphically in Figure 6. Foundering of the

367 subducted Rheic slab may have led to the initiation of Pangean rifting in this region prior to 200

368 Ma, but a large, pan-Appalachian delamination at 200 Ma spurred CAMP magmatism and

369 accelerated the rifting of Pangea (Whalen et al., 2015). This delamination would have occurred

370 beneath the ancestral orogenic hinterland, which lies beneath the modern Piedmont and Coastal

371 Plain, and would have removed the lowermost, likely eclogitized crust. Fertile asthenospheric

372 peridotite would then upwell to fill the void left by this delamination.

373 If the regrown sub-Piedmont lithosphere were highly fertile, so that the constituent rocks

374 have very low magnesium numbers; rich in pyroxenes, so that any constituent lherzolites could

375 almost be classified as olivine websterites; and/or rich in mantle pyroxenite, then the structure

376 that we observe here could be seismically invisible (Cammarano et al., 2003; Lee, 2003; Schutt

377 and Lesher, 2010; Erdman et al., 2016). If the step in the LAB between these two lithospheric

378 domains were $\sim 50 \mathrm{~km}$, then for reasonable conductive geotherms the temperature contrast would

379 be small enough for compositional differences to offset the temperature difference. Such unusual

380 mantle compositions could reconcile the MT and the seismic results as long as the regrown

381 lithosphere were minimally hydrated. Excess mantle water could have been removed during

382 CAMP magmatism. The heterogeneity observed in local body-wave tomography (Biryol et al.,

383 2016) may reflect compositional variations in this regrown lithosphere root.

384 Such atypical mantle lithologies could form if the regrown lithosphere trapped abundant

385 asthenospheric melts or if the upwelling asthenosphere consumed significant amounts of the 
386 delaminated lithosphere. The Alleghenian lithosphere was likely hydrated to some extent;

387 lithospheric absorption of asthenospheric melts that were generated during dehydration of the 388 delaminant (e.g., Elkins-Tanton, 2005) could result in fertilization of the regrown sub-Piedmont 389 lithosphere. If the Alleghenian lithosphere were already warm, as would be expected following 390 orogenesis, and if it detached slowly, then melting of the delamination itself would be expected 391 (Wang and Currie, 2015). Indeed, the geochemistry of CAMP lavas indicates a shallow-mantle 392 pyroxenite source (Whalen et al., 2015), so delaminated material must have melted to feed this 393 continental flood basalt. By assimilating this melt, the upwelling asthenosphere could have 394 become enriched in a pyroxene component or effectively metasomatized. Global geochemical 395 studies indicate that assimilation of eclogitic material can indeed produce abundant secondary 396 mantle pyroxenite (e.g., Sobolev et al., 2007).

With the transition from an active rift zone to a passive margin, the eastern margin of North America would have cooled and subsided. Especially because particularly fertile lithosphere would be relatively dense (Cammarano et al., 2003; Lee, 2003), subsidence of the regrown root could have resulted in a depressed LAB that is still intact today (Fig. 6). Stability of this thick root could be maintained if the constituent mantle rocks remain dry, as the MT data indicate they are, and thereby strong. Further work will be necessary to rigorously test the geodynamic and geochemical requirements and consequences of this possible model.

Seismic studies suggest that the crust beneath the modern Appalachian highlands is thicker than the crust beneath the Piedmont lowlands (Hawman et al., 2012; Schmandt et al., 2015; Shen and Ritzwoller, 2016). The model proposed here could provide an explanation for thinner crust in the ancestral orogenic hinterland compared to the ancestral foreland, as the lower Piedmont crust would have been removed during the delamination event. 
An isostatic gravity high that spatially coincides with the highly resistive structure imaged

410 here (R1; Figs. 2, 4; Simpson et al., 1986) also supports the existence of exceptionally fertile,

411 dense lithosphere beneath the Piedmont. Although this Appalachian-parallel isostatic high has

412 been interpreted as due in part to mafic lithologies such as CAMP lavas, a single coherent

413 explanation for its origin has been lacking (Simpson et al., 1986). The model that we propose

414 here provides such an explanation for this gravity signal.

Thermal measurements from the southeastern United States show that heat flow is generally

416 higher in the Piedmont than in the adjacent Appalachians (Smith et al., 1981), seemingly in

417 contrast to what would be expected for the thick sub-Piedmont thermal lithosphere that we image

418 here. However, differences in heat production between the rocks of the Appalachian crust and the

419 rocks of the Piedmont crust could mask the deeper mantle heat-flow signature. Alternatively,

420 higher heat production within the thick, fertile sub-Piedmont lithosphere could yield a higher

421 heat flow than from the adjacent sub-Appalachian lithosphere. In this scenario, the temperature

422 difference between the sub-Piedmont mantle and the adjacent sub-Appalachian mantle could be

423 diminished by high internal heat production in the fertile sub-Piedmont lithospheric root. This

424 low thermal contrast would then certainly allow compositional effects to exert significant control

425 on seismic wave speeds.

426 Recent seismic body-wave tomography has been used to argue for continuing piecemeal

427 delamination of the lithosphere beneath the southeastern United States (Biryol et al., 2016).

428 Based on our results here, particularly our observation of the coherently resistive nature of the

429 sub-Piedmont lithosphere, we cannot support the interpretation that delamination events occurred

$430 \quad$ throughout the Cenozoic and are still occurring at present. 


\subsubsection{Implications for Appalachian Topographic Rejuvenation}

433

434

Regardless of the exact nature and history of this anomalously thick sub-Piedmont lithosphere, its existence does indicate a major, previously unappreciated contrast in the upper mantle beneath the southeastern United States. The spatial correspondence between this lithospheric boundary and the modern Appalachian topographic scarp (Fig. 2) is likely not a coincidence; rather, this contrast in lithospheric properties may hold important consequences for Appalachian topographic rejuvenation.

Edge-driven, small-scale convection at the boundary between relatively thin Appalachian lithosphere and relatively thick Piedmont lithosphere could have driven the episodes of topographic rejuvenation that are suggested by the geomorphic, thermochronologic, and Atlantic sedimentary records (Fig. 6). Shear-induced flow associated with overall mantle motion beneath eastern North America could drive such a small convection cell (Fig. 6; Kaislaniemi and van Hunen, 2014). Vertical mantle flow associated with edge convection in this region may be responsible for elongating the edge of this resistive anomaly with depth (Kaislaniemi and van Hunen, 2014), so that it may in fact extend to depths significantly greater than $200 \mathrm{~km}$. Hydration of the sub-Appalachian lithospheric mantle by dewatering of the Farallon slab (van der Lee et al., 2008) could have played an important role in enabling this small-scale convection.

\section{Conclusions}

Inversion of MT data from the southeastern United States provides new insights into the architecture of the Appalachian Orogen and also reveals the presence of an anomalous lithospheric block beneath the Piedmont and Coastal Plain. Based on these MT data, the lithosphere beneath the Piedmont must extend to $>200 \mathrm{~km}$ depth. In contrast, the lithosphere 
455 beneath the modern Appalachians only extends to 150-200 km depth. Although such relatively

456 thick Piedmont lithosphere has not been observed by seismic studies, the MT data require low

457 temperatures $\left(\sim 1100^{\circ} \mathrm{C}\right)$ to depths of $\sim 200 \mathrm{~km}$. This lithospheric step is therefore robust.

458 The origin of the thick sub-Piedmont lithosphere and the cause of its apparent long-term

459 geodynamic stability are unclear at present. However, the contrast between highly resistive

460 lithosphere and moderately conductive lithosphere corresponds to the topographic escarpment of

461 the modern Appalachian Mountains. This structure therefore likely holds important implications

462 for Appalachian topographic rejuvenation. We propose that it has enabled edge-driven

463 convection that has provided dynamic support for topography in the eastern United States.

464 Further detailed study of this region is clearly warranted. Future collaboration with

465 seismologists, geodynamicists, and geochemists is necessary in order to better characterize the

466 composition and physical state of the Piedmont resistor and to explore the implications of this

467 structure for the past and present geodynamics of the southeastern United States. The eastern

468 boundary of this structure is poorly resolved at present due to the current limits of our dataset. A

469 seafloor MT survey offshore of North Carolina, South Carolina, and Georgia would be

470 tremendously beneficial in better understanding this region.

\section{Acknowledgements}

We thank Emily Hart, Kyle Jones, Allen Hooper, Kyle McDonald, Taryn Bye, Eleanor

474 Kester, Lana Erofeeva, Brady Fry, Lu Pellerin, and Adam Schultz for their work in collecting and

475 processing these data. Bo Yang and Naser Meqbel assisted greatly with use of ModEM in this

476 project. Conversations with and input from Nikki Moore, Phil Wannamaker, Dave Graham, Gene

477 Humphreys, Steve Constable, Paul Bedrosian, and Eric Kirby greatly benefited this work. We 
478 thank Rob Harris and Brandon Schmandt for valuable feedback on a preliminary version of this

479 paper. We also thank Kate Selway, Ian Ferguson, and Peter Shearer for very helpful reviews of

480 the manuscript.

481 This research was supported by NSF Grant EAR1053628 and by the NSF Graduate Research 482 Fellowship Program under Grant 1314109-DGE.

483

$484 \quad$ References

485 Abbott, R.N., Greenwood, J.P., 2001. Retrograde metamorphism of eclogite in the southern

486 Appalachian Mountains, U.S.A.-A case involving seamount subduction? Journal of

487 Metamorphic Geology 19, 433-443. http://dx.doi.org/10.1046/j.0263-4929.2001.00321.x.

488

489 Ardia, P., Hirschmann, M.M., Withers, A.C., Tenner, T.J., 2012. $\mathrm{H}_{2} \mathrm{O}$ storage capacity of olivine

490 at 5-8 GPa and consequences for dehydration partial melting of the upper mantle. Earth and

491 Planetary Science Letters 345-348, 104-116. http://dx.doi.org/10.1016/j.eps1.2012.05.038.

492

493 Biryol, C.B., Wagner, L.S., Fischer, K.M., Hawman, R.B., 2016. Relationship between observed 494 upper mantle structures and recent tectonic activity across the Southeastern United States.

495 Journal of Geophysical Research: Solid Earth 121, 3393-3414.

496 http://dx.doi.org/10.1002/2015JB012698.

497

498 Boerner, D.E., Kurtz, R.D., Craven, J.A., 1996. Electrical conductivity and Paleo-Proterozoic 499 foredeeps. Journal of Geophysical Research 101, 13775-13791.

$500 \quad$ http://dx.doi.org/10.1029/96JB00171. 
502 Boote, S.K., Knapp, J.H., 2016. Offshore extent of Gondwanan Paleozoic strata in the

503 southeastern United States: The Suwannee suture zone revisited. Gondwana Research 40, 199-

504 210. http://dx.doi.org/10.1016/j.gr.2016.08.011.

505

506 Cammarano, F., Goes, S., Vacher, P., Giardini, D., 2003. Inferring upper-mantle temperatures

507 from seismic velocities. Physics of the Earth and Planetary Interiors 138, 197-222.

$508 \quad$ http://dx.doi.org/10.1016/S0031-9201(03)00156-0.

509

510 Chu, R., Leng, W., Helmberger, D.V., Gurnis, M., 2013. Hidden hotspot track beneath the eastern

511 United States. Nature Geoscience 6, 963-966. http://dx.doi.org/10.1038/ngeo1949.

512

513 Constable, S., 2006. SEO3: A new model of olivine electrical conductivity. Geophysical Journal

514 International 166, 435-437. http://dx.doi.org/10.1111/j.1365-246X.2006.03041.x.

515

516 Cook, F.A., Vasudevan, K., 2006. Reprocessing and enhanced interpretation of the initial

517 COCORP Southern Appalachians traverse. Tectonophysics 420, 161-174.

518 http://dx.doi.org/10.1016/j.tecto.2006.01.022.

520 Cox, R.T., Van Arsdale, R.B., 2002. The Mississippi Embayment, North America: a first order

521 continental structure generated by the Cretaceous superplume mantle event. Journal of

522 Geodynamics 34, 163-176. http://dx.doi.org/10.1016/S0264-3707(02)00019-4. 
524 Dai, L., Karato, S., 2014. High and highly anisotropic electrical conductivity of the

525 asthenosphere due to hydrogen diffusion in olivine. Earth and Planetary Science Letters 408, 79-

526 86. http://dx.doi.org/10.1016/j.epsl.2014.10.003.

527

528 Du Frane, W.L., Roberts, J.J., Toffelmier, D.A., Tyburczy, J.A., 2005. Anisotropy of electrical 529 conductivity in dry olivine. Geophysical Research Letters 32, L24315.

$530 \quad$ http://dx.doi.org/10.1029/2005GL023879.

532 Elkins-Tanton, L.T., 2005. Continental magmatism caused by lithospheric delamination. In

533 Foulger, G.R., Natland, J.H., Presnall, D.C., Anderson, D.L., eds. Plates, plumes, and paradigms.

534 Geological Society of America Special Paper 388, 449-461. http://dx.doi.org/10.1130/0-8137-

$535 \quad \underline{2388-4.449}$.

536

537 Elliott, S., 1998. The Physics and Chemistry of Solids, Wiley, England.

538

539 Erdman, M.E., Lee, C.-T. A., Levander, A., Jiang, H., 2016. Role of arc magmatism and lower

540 crustal foundering in controlling elevation history of the Nevadaplano and Colorado Plateau: A

541 case study of pyroxenitic lower crust from central Arizona, USA. Earth and Planetary Science

542 Letters 439, 48-57. http://dx.doi.org/10.1016/j.eps1.2016.01.032.

543

544 Fisher, C.M., Loewy, S.L., Miller, C.F., Berquist, P., Van Schmus, W.R., Hatcher, R.D., Jr.,

545 Wooden, J.L., Fullagar, P.D., 2010. Whole-rock $\mathrm{Pb}$ and Sm-Nd isotopic constraints on the growth 
546 of southeastern Laurentia during Grenvillian orogenesis. Geological Society of America Bulletin $547 \quad$ 122, 1646-1659. http://dx.doi.org/10.1130/B30116.1.

549 Frizon de Lamotte, D., Fourdan, B., Leleu, S., Leparmentier, F., de Clarens, P., 2015. Style of 550 rifting and the stages of Pangea breakup. Tectonics 34, 1009-1029.

$551 \quad$ http://dx.doi.org/10.1002/2014TC003760.

552

553 Fullea, J., Muller, M.R., Jones, A.G., 2011. Electrical conductivity of continental lithospheric 554 mantle from integrated geophysical and petrological modeling: Application to the Kaapvaal 555 Craton and Rehoboth Terrane, southern Africa. Journal of Geophysical Research 116, B10202. $556 \quad$ http://dx.doi.org/10.1029/2011JB008544.

558 Gallen, S.F., Wegmann, K.W., Bohnenstiehl, D.R., 2013. Miocene rejuvenation of topographic 559 relief in the southern Appalachians. GSA Today 23, 4-10.

560 http://dx.doi.org/10.1130/GSATG163A.1.

562 Gardés, E., Gaillard, F., Tarits, P., 2014. Toward a unified hydrous olivine electrical conductivity 563 law. Geochemistry, Geophysics, Geosystems 15, 4984-5000.

564 http://dx.doi.org/10.1002/2014GC005496.

566 González-Castillo, L., Galindo-Zaldívar, J., Junge, A., Martínez-Moreno, F.J., Löwer, A., Sanz de 567 Galdeano, C., Pedrera, A., López-Garrido, A.C., Ruiz-Constán, A., Ruano, P., Martínez-Martos, 568 M., 2015. Evidence of a large deep conductive body within the basement of Guadalquivir 
569 foreland Basin (Betic Cordillera, S-Spain) from tipper vector modelling: Tectonic implications.

570 Tectonophysics 663, 354-363. http://dx.doi.org/10.1016/j.tecto.2015.08.013.

572 Hatcher, R.D., Jr., 2010. The Appalachian orogen: A brief summary, in Tollo, R.P., Bartholomew, 573 M.J., Hibbard J.P., and Karabinos, P.M., eds., From Rodinia to Pangea: The Lithotectonic Record 574 of the Appalachian Region. Geological Society of America Memoir 206, 1-19.

575 http://dx.doi.org/10.1130/2010.1206(01).

576

577 Hawman, R.B., Khalifa, M.O., Baker, M.S., 2012. Isostatic compensation for a portion of the

578 Southern Appalachians: Evidence from a reconnaissance study using wide-angle, three-

579 component seismic soundings. Geological Society of America Bulletin 124, 291-317.

$580 \quad$ http://dx.doi.org/10.1130/B30464.1.

582 Hibbard, J.P., van Staal, C.R., Rankin, C.W., 2010. Comparative analysis of the geological 583 evolution of the northern and southern Appalachian orogen: Late Ordovician-Permian. In Tollo, 584 R.P., Bartholomew, M.J., Hibbard, J.P., Karabinos, P.M., eds., From Rodinia to Pangea: The 585 Lithotectonic Record of the Appalachian Region. Geological Society of America Memoir 206, 586 51-69. http://dx.doi.org/10.1130/2010.1206(03).

588 Hopper, E., Fischer, K.M., Wagner, L.S., Hawman, R.B., 2017. Reconstructing the end of the 589 Appalachian orogen. Geology 45, 15-18. http://dx.doi.org/10.1130/G38453.1. 
591 Jones, A.G., Ledo, J., Ferguson, I.J., 2005. Electromagnetic images of the Trans-Hudson orogen:

592 the North American Central Plains anomaly revealed. Canadian Journal of Earth Sciences 32,

593 457-478. http://dx.doi.org/10.1139/e05-018.

594

595 Jones, A.G., Fullea, J., Evans, R.L., Muller, M.R., 2012. Water in cratonic lithosphere:

596 Calibrating laboratory-determined models of electrical conductivity of mantle minerals using

597 geophysical and petrological observations. Geochemistry, Geophysics, Geosystems 13, 27.

$598 \quad$ http://dx.doi.org/10.1029/2012GC004055.

599

600 Kaislaniemi, L., van Hunen, J., 2014. Dynamics of lithospheric thinning and mantle melting by 601 edge-driven convection: Application to Moroccan Atlas mountains. Geochemistry, Geophysics, 602 Geosystems 15, 3175-3189. http://dx.doi.org/10.1002/2014GC005414.

603

604 Kelbert, A., Meqbel, N., Egbert, G.D., Tandon, K., 2014. ModEM: A modular system for 605 inversion of electromagnetic geophysical data. Computers \& Geosciences 66, 40-53. $606 \quad$ http://dx.doi.org/10.1016/j.cageo.2014.01.010.

607

608 Keppler, H., Bolfan-Casanova, N., 2006. Thermodynamics of Water Solubility and Partitioning. 609 In Keppler, H., Smyth, J.R., eds. Water in Nominally Anhydrous Minerals. Reviews in 610 Mineralogy and Geochemistry 62, 193-230. http://dx.doi.org/10.2138/rmg.2006.62.9.

612 Lee, C.-T. A., 2003. Compositional variation of density and seismic velocities in natural 613 peridotites at STP conditions: Implications for seismic imaging of compositional heterogeneities 
614 in the upper mantle. Journal of Geophysical Research 108, B92441.

615 http://dx.doi.org/10.1029/2003JB002413.

616

617 Liu, L., 2014. Rejuvenation of Appalachian topography caused by subsidence-induced

618 differential erosion. Nature Geoscience 7, 518-523. http://dx.doi.org/10.1038/ngeo2187.

619

620 Long, M.D., Jackson, K.G., McNamara, J.F., 2016. SKS splitting beneath Transportable Array

621 stations in eastern North America and the signature of past lithospheric deformation.

622 Geochemistry, Geophysics, Geosystems 17, 2-15. http://dx.doi.org/10.1002/2015GC006088.

623

624 MacDougall, J.G., Fischer, K.M., Forsyth, D.W., Hawman, R.B., Wagner, L.S., 2015. Shallow

625 mantle velocities beneath the southern Appalachians from Pn phases. Geophysical Research

626 Letters 42, 339-345. http://dx.doi.org/10.1002/2014GL062714.

627

628 Mazza, S.E., Gazel, E., Johnson, E.A., Kunk, M.J., McAleer, R., Spotila, J.A., Bizimis, M.,

629 Coleman, D.S., 2014. Volcanoes of the passive margin: The youngest magmatic event in eastern

$630 \quad$ North America. Geology 42, 483-486. http://dx.doi.org/10.1130/G35407.1.

631

632 McKeon, R.E., Zeitler, P.K., Pazzaglia, F.J., Idleman, B.D., Enkelmann, E., 2014. Decay of an

633 old orogen: Inferences about Appalachian landscape evolution from low-temperature

634 thermochronology. Geological Society of America Bulletin 126, 31-46.

$635 \quad$ http://dx.doi.org/10.1130/B30808.1. 
637 Miller, S.R., Sak, P.B., Kirby, E., Bierman, P.R., 2013. Neogene rejuvenation of central

638 Appalachian topography: Evidence for differential rock uplift from stream profiles and erosion

639 rates. Earth and Planetary Science Letters 369-370, 1-12.

$640 \quad$ http://dx.doi.org/10.1016/j.epsl.2013.04.007.

642 Moucha, R., Forte, A.M., Mitrovica, J.X., Rowley, D.B., Quéré, S., Simmons, N.A., Grand, S.P., 643 2008. Dynamic topography and long-term sea-level variations: There is no such thing as a stable 644 continental platform. Earth and Planetary Science Letters 271, 101-108.

$645 \quad$ http://dx.doi.org/10.1016/j.epsl.2008.03.056.

646

647 Ogawa, Y., Jones, A.G., Unsworth, M.J., Booker, J.R., Lu, X., Craven, J., Roberts, B., Parmelee, 648 J., Farquharson, C., 1996. Deep electrical conductivity structures of the Appalachian Orogen in 649 the southeastern U.S. Geophysical Research Letters 23, 1597-1600.

650 http://dx.doi.org/10.1029/95GL03601.

652 Phillips, J.D., Duval, J.S., Ambroziak, R.A., 1993. National geophysical data grids: gamma-ray, 653 gravity, magnetic, and topographic data for the conterminous United States. United States

654 Geological Survey Digital Data Series 9. http://mrdata.usgs.gov/geophysics/gravity.html 655 (accessed Oct. 1, 2016).

656

657 Poag, C.W., Sevon, W.D., 1989. A record of Appalachian denudation in postrift Mesozoic and 658 Cenozoic sedimentary deposits of the U.S. Middle Atlantic continental margin. Geomorphology $659 \quad 2,119-157$. http://dx.doi.org/10.1016/0169-555X(89)90009-3. 
661 Pollitz, F.F., Mooney, W.D., 2016. Seismic velocity structure of the crust and shallow mantle of 662 the Central and Eastern United States by seismic surface wave imaging. Geophysical Research 663 Letters 43, 118-126. http://dx.doi.org/10.1002/2015GL066637.

664

665 Prince, P.S., Spotila, J.A., 2013. Evidence of transient topographic disequilibrium in the

666 landward passive margin river system: knickpoints and paleo-landscapes of the New River basin, 667 southern Appalachians. Earth Surface Processes and Landforms 38, 1685-1699.

668 http://dx.doi.org/10.1002/esp.3406.

669

670 Schmandt, B., Lin, F.-C., 2014. $P$ and $S$ wave tomography of the mantle beneath the United

671 States. Geophysical Research Letters 41, 6342-6349. http://dx.doi.org/10.1002/2014GL061231.

672

673 Schmandt, B., Lin, F.-C., Karlstrom, K.E., 2015. Distinct crustal isostasy trends east and west of 674 the Rocky Mountain Front. Geophysical Research Letters 42, 10290-10298.

675 http://dx.doi.org/10.1002/2015GL066593.

676

677 Schutt, D.L., Lesher, C.E., 2010. Compositional trends among Kaapvaal Craton garnet peridotite 678 xenoliths and their effects on seismic velocity and density. Earth and Planetary Science Letters 679 300, 367-373. http://dx.doi.org/10.1016/j.eps1.2010.10.018.

680

681 Selway, K., 2014. On the Causes of Electrical Conductivity Anomalies in Tectonically Stable 682 Lithosphere. Surveys in Geophysics 35, 219-257. http://dx.doi.org/10.1007/s10712-013-9235-1. 
684 Shen, W., Ritzwoller, M.H., 2016. Crustal and uppermost mantle structure beneath the United 685 States. Journal of Geophysical Research: Solid Earth 121, 37.

686 http://dx.doi.org/10.1002/2016JB012887.

687

688 Simpson, R.W., Jachens, R.C., Blakely, R.J., Saltus, R.W., 1986. A New Isostatic Residual 689 Gravity Map of the Conterminous United States With a Discussion on the Significance of $690 \quad$ Isostatic Residual Anomalies. Journal of Geophysical Research 91, 8348-8372.

$691 \quad$ http://dx.doi.org/10.1029/JB091iB08p08348.

692

693 Smith, D.L., Gregory, R.G., Emhof, J.W., 1981. Geothermal Measurements in the Southern 694 Appalachian Mountains and Southeastern Coastal Plains. American Journal of Science 281, 282695 298. http://dx.doi.org/10.2475/ajs.281.3.282.

696

697 Sobolev, A.V., Hofmann, A.W., Kuzmin, D.V., Yaxley, G.M., Arndt, N.T., Chung, S.-L., 698 Danyushevsky, L.V., Elliott, T., Frey, F.A., Garcia, M.O., Gurenko, A.A., Kamenetsky, V.S., 699 Kerr, A.C., Krivolutskaya, N.A., Matvienkov, V.V., Nikogosian, I.K., Rocholl, A., Sigurdsson, 700 I.A., Sushchevskaya, N.M., Teklay, M., 2007. The Amount of Recycled Crust in Sources of 701 Mantle-Derived Melts. Science 316, 412-417. http://dx.doi.org/10.1126/science. 1138113.

703 Spasojević, S., Liu, L., Gurnis, M., Müller, R.D., 2008. The case for dynamic subsidence of the 704 U.S. east coast since the Eocene. Geophysical Research Letters 35, L08305. 705 http://dx.doi.org/10.1029/2008GL033511. 
707 Steltenpohl, M.G., Zietz, I., Horton, J.W., Jr., Daniels, D.L., 2010. New York-Alabama

708 lineament: A buried right-slip fault bordering the Appalachians and mid-continent North

709 America. Geology 38, 571-574. http://dx.doi.org/10.1130/G30978.1.

710

711 van der Lee, S., Regenauer-Lieb, K., Yuen, D.A., 2008. The role of water in connecting past and 712 future episodes of subduction. Earth and Planetary Science Letters 273, 15-27.

$713 \quad$ http://dx.doi.org/10.1016/j.eps1.2008.04.041.

714

715 Wagner, L.S., Stewart, K., Metcalf, K., 2012. Crustal-scale shortening structures beneath the

716 Blue Ridge Mountains, North Carolina, USA. Lithosphere 4, 242-256.

717 http://dx.doi.org/10.1130/L184.1.

718

719 Wang, H., Currie, C.A., 2015. Magmatic expressions of continental lithosphere removal. Journal 720 of Geophysical Research: Solid Earth 120, 7239-7260. http://dx.doi.org/10.1002/2015JB012112.

722 Wannamaker, P.E., 2005. Anisotropy versus Heterogeneity in Continental Solid Earth 723 Electromagnetic Studies: Fundamental Response Characteristics and Implications for 724 Physicochemical State. Surveys in Geophysics 26, 733-765. http://dx.doi.org/10.1007/s10712$725 \quad \underline{005-1832-1}$.

726

727 Whalen, L., Gazel, E., Vidito, C., Puffer, J., Bizimis, M., Henika, W., Caddick, M.J., 2015.

728 Supercontinental inheritance and its influence on supercontinental breakup: The Central Atlantic 
729 Magmatic Province and the breakup of Pangea. Geochemistry, Geophysics, Geosystems 16,

$730 \quad 3532-3554$. http://dx.doi.org/10.1002/2015GC005885.

732 Willett, S.D., McCoy, S.W., Perron, J.T., Goren, L., Chen, C.-Y., 2014. Dynamic Reorganization 733 of River Basins. Science 343, 9. http://dx.doi.org/10.1126/science.1248765.

735 Yang, B., Egbert, G.D., Kelbert, A., Meqbel, N.M., 2015. Three-dimensional electrical resistivity 736 of the north-central USA from EarthScope long period magnetotelluric data. Earth and Planetary 737 Science Letters 422, 87-93. http://dx.doi.org/10.1016/j.epsl.2015.04.006.

739 Yoshino, T., Matsuzaki, T., Shatskiy, A., Katsura, T., 2009. The effect of water on the electrical 740 conductivity of olivine aggregates and its implications for the electrical structure of the upper 741 mantle. Earth and Planetary Science Letters 288, 291-300.

$742 \quad$ http://dx.doi.org/10.1016/j.epsl.2009.09.032.

\section{$744 \quad$ Figure Captions}

745 Figure 1: Overview map of the study region. Orange inverted triangles indicate EarthScope MT 746 sites that constitute our dataset. Black solid lines delineate major terrane boundaries as 747 determined from geologic datasets (adapted from Hatcher, 2010). Black dotted line indicates the 748 recently reinterpreted surface trace of the Suwannee suture (Boote and Knapp, 2016; Hopper et

749 al., 2017). White dashed lines divide the major physiographic provinces referenced in the text 750 (adapted from USGS physiographic province dataset). Basemap shows modern Southern 751 Appalachian topography. Abbreviations for US states that are shown on the map are as follows: 


\section{Carolina; GA, Georgia; AL, Alabama.}

755 Figure 2: Depth slices and cross sections through the preferred inverse solution. Each cross 756 section is paired with the corresponding topographic profile. Labels that begin with $C$ denote 757 well-resolved conductive structures that are described in the text; labels that begin with $E C$ 758 denote poorly resolved conductive features mentioned in the text; and labels that begin with $R$ 759 denote resistive structures discussed in the text. The off-shore southeastern limit of R1 is poorly 760 resolved at present; see Figure S7 and the accompanying text in the Supplementary Materials for 761 a discussion of resolution.

763 Figure 3: Vertical magnetic field transfer function data (tippers) at $1092 \mathrm{~s}$ plotted as induction 764 vectors with the Parkinson sign convention. When plotted in this manner, these arrows point 765 towards anomalous conductivity contrasts. These data delineate a feature along which the 766 induction vectors change direction by $180^{\circ}$ in the northwestern portion of our data coverage. 767 This linear feature corresponds to the trace of the New York-Alabama (NY-AL) Lineament. The 768 induction vectors from the vast majority of the southern sites in our dataset point towards a major 769 conductivity contrast beyond our spatial footprint to the southwest, in southern Alabama or the 770 northern Gulf of Mexico.

772 Figure 4: Isostatic gravity map for the southeastern United States (from Phillips et al., 1993; data 773 available at http://mrdata.usgs.gov/geophysics/gravity.html). Note the relative isostatic gravity 
774 low that spatially corresponds to electrically conductive structure C5. The major Appalachian-

775 parallel isostatic gravity high coincides with electrically resistive structure R1.

777 Figure 5: Resistivity as a function of temperature for olivine (ol), orthopyroxene (opx), and 778 clinopyroxene (cpx). As these three minerals are the dominant phases in the upper mantle, they 779 will control mantle resistivity values (Fullea et al. 2011, Selway 2014). Black lines are for dry

780 olivine and demonstrate the minimal effect that compositional variations have on electrical 781 conductivity (compositional effects are similarly small for pyroxenes). Red and green lines are 782 representative of dry orthopyroxene and clinopyroxene resistivity, respectively. Blue lines 783 demonstrate the effects of adding small amounts of water to mantle minerals. The blue-shaded 784 region denotes the resistivity values that are observed for structure $\mathrm{R} 1$. The green-shaded region 785 denotes resistivity values that are observed for the region beneath the modern Appalachian

786 highlands. The curves plotted here are representative of mantle mineral resistivities as a function 787 of temperature. Other calibrations differ slightly but are generally in agreement with those shown 788 here. These calibrations are from Fullea et al. (2011), Jones et al. (2012), and Gardés et al. 789 (2014).

791 Figure 6: Possible model for the formation of the sub-Piedmont lithospheric resistor.

792 Delamination of pyroxenite-rich mantle and eclogitized lower crust from the Alleghenian Orogen 793 leads to CAMP magmatism as well as development of a void in the Appalachian lithosphere that 794 is filled by upwelling asthenosphere. This asthenospheric mantle assimilates material from the 795 delaminant and thereby becomes highly fertilized or metasomatized. As the eastern Laurentian 796 margin cools after opening of the Atlantic, this region subsides. Lithospheric cooling and the 
797 high density of the fertile regrown root allow for development of a step in the LAB, which now 798 supports edge convection that can drive topographic disequilibrium. 


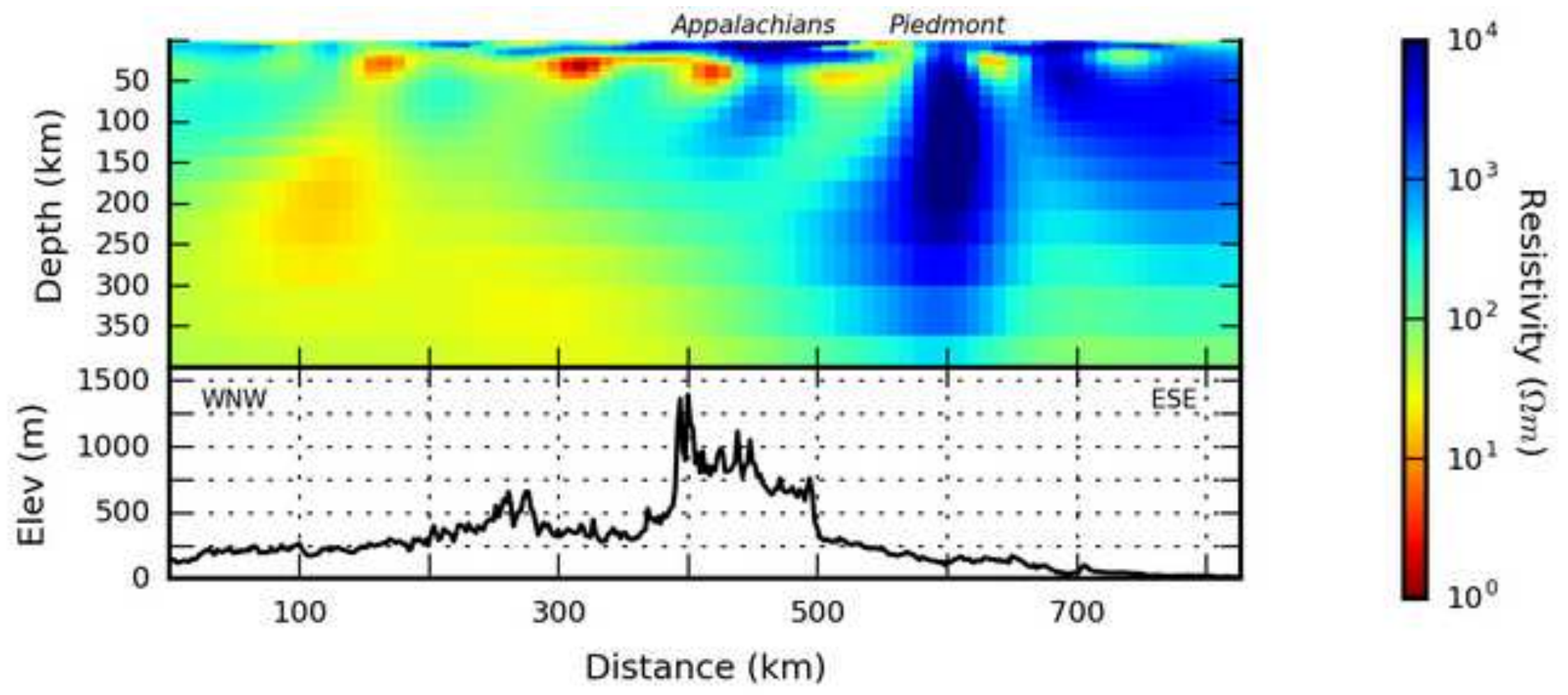




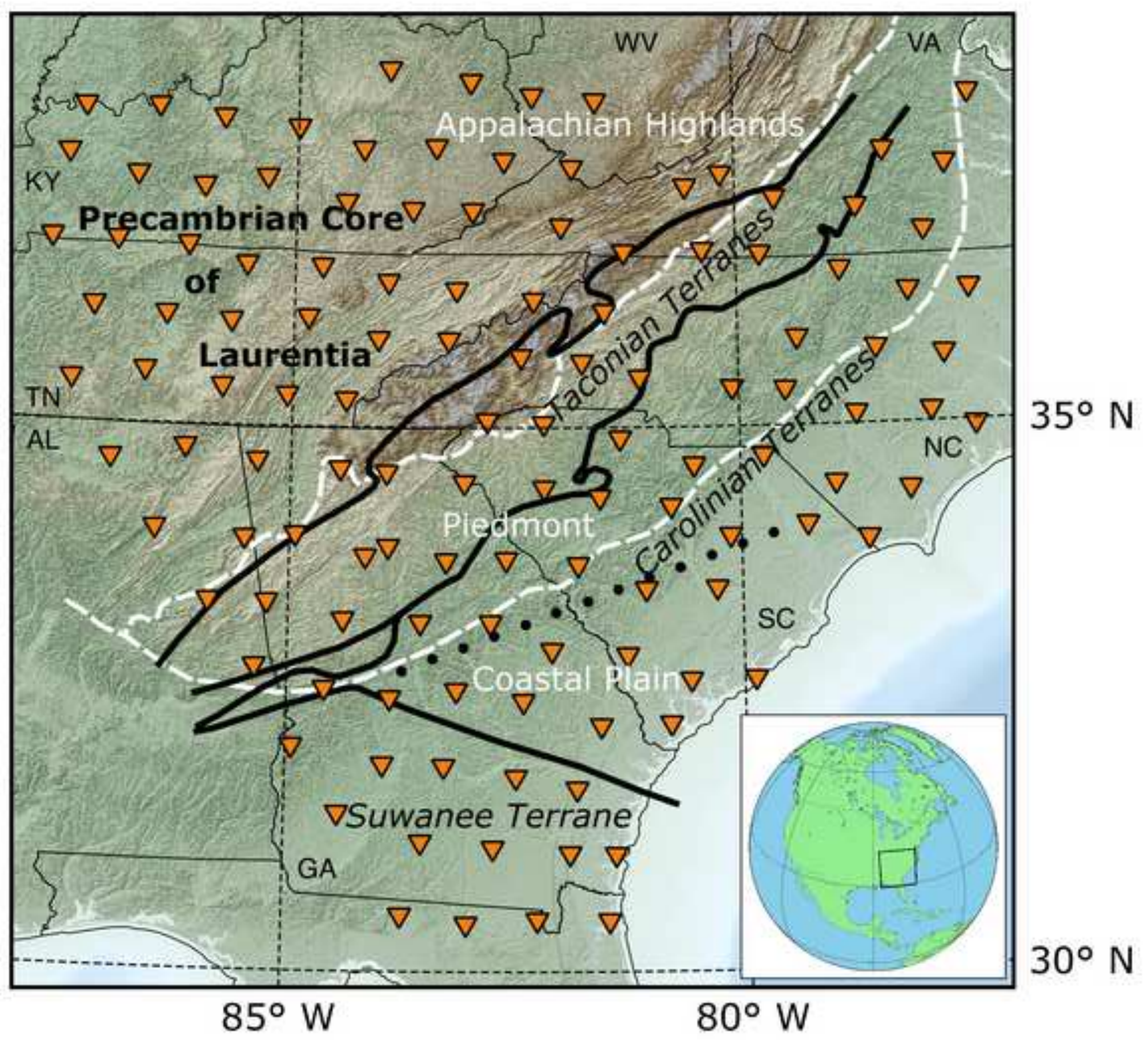



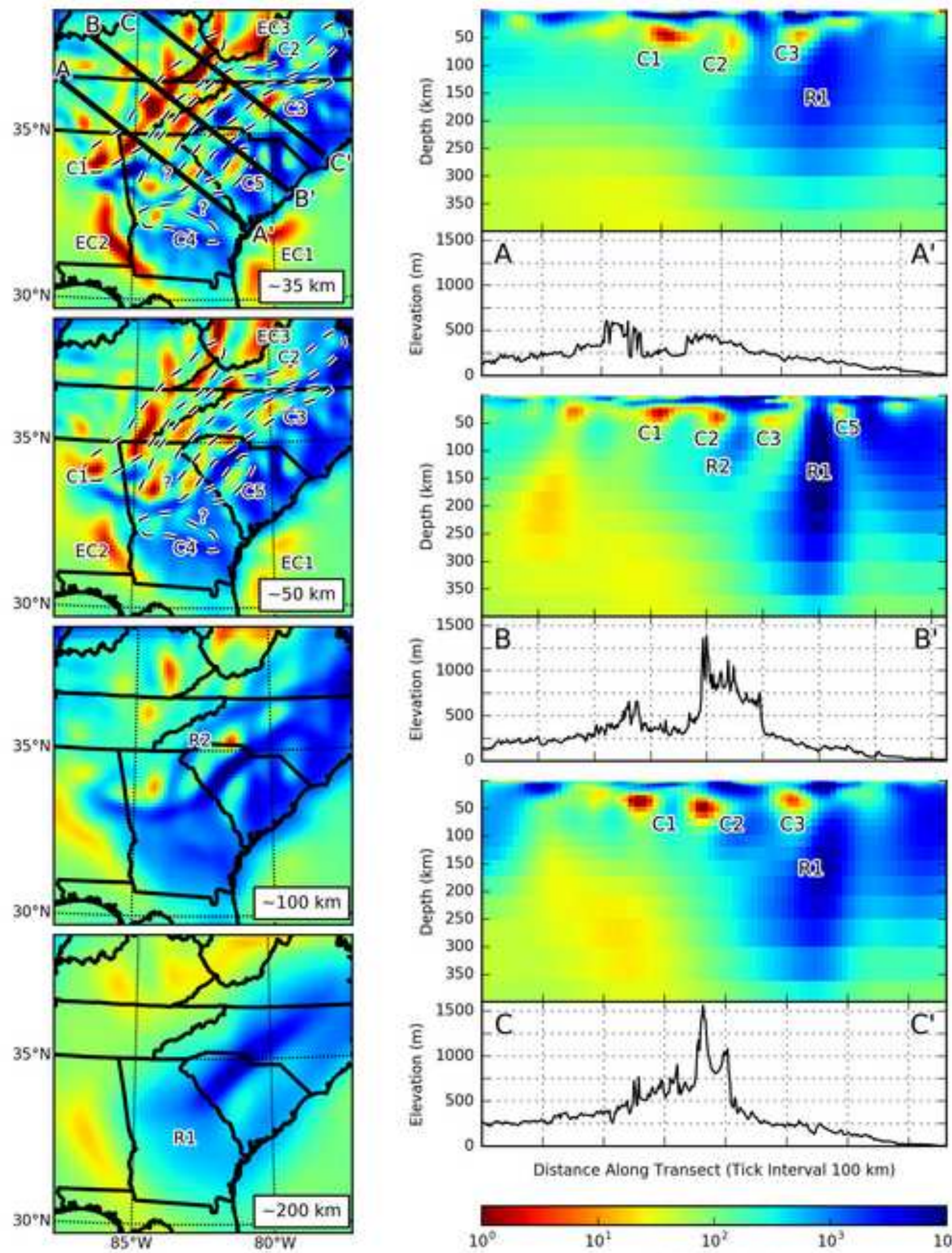

Distance Along Transect (Tick Interval $100 \mathrm{~km}$ )

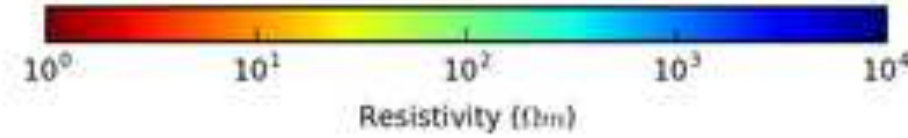


Figure 3

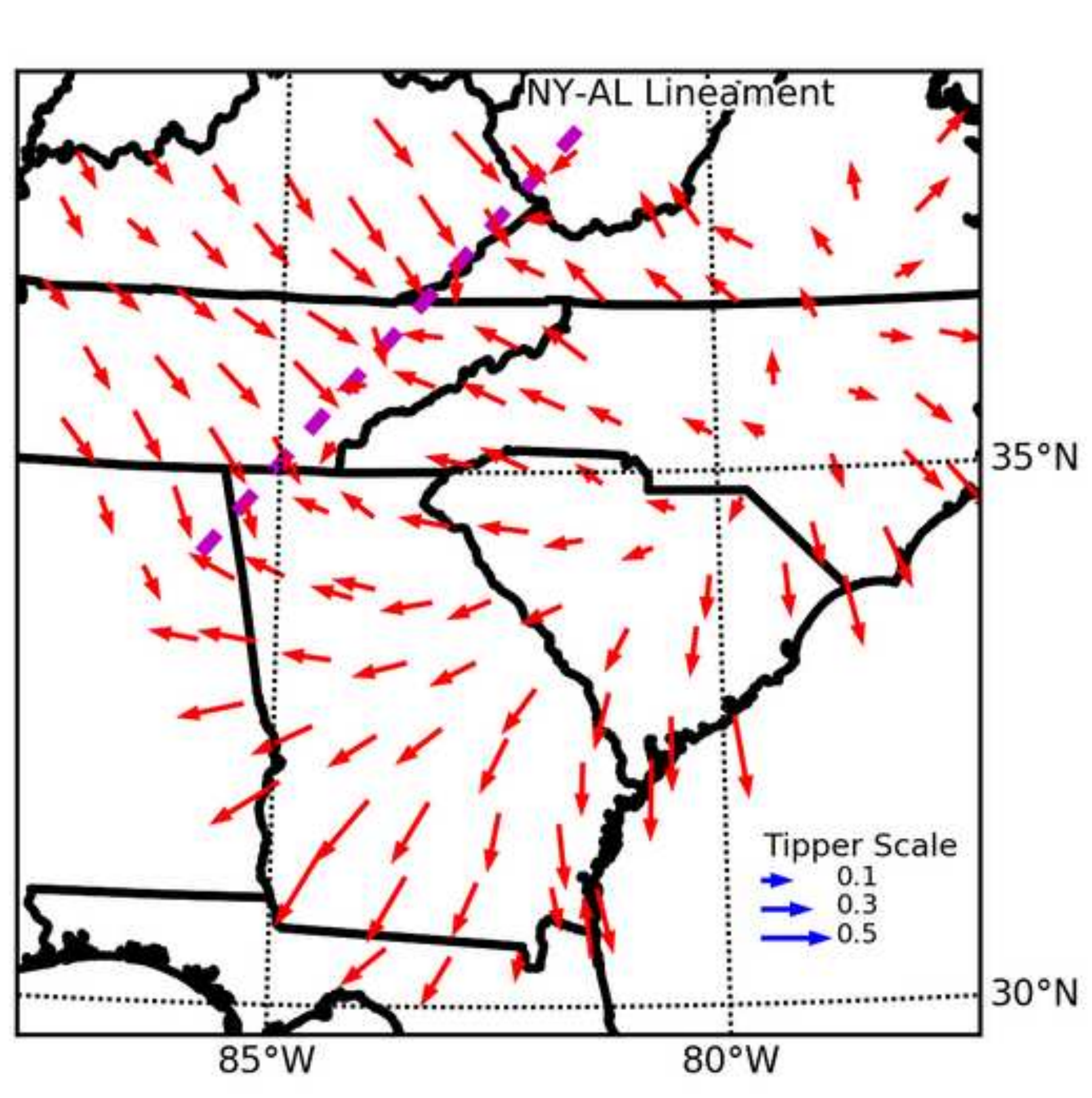

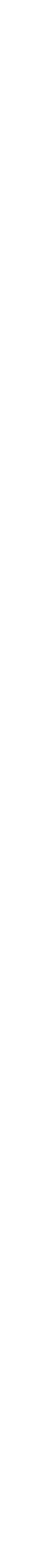

\begin{abstract}
Figure 3
Fin
\end{abstract}

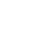
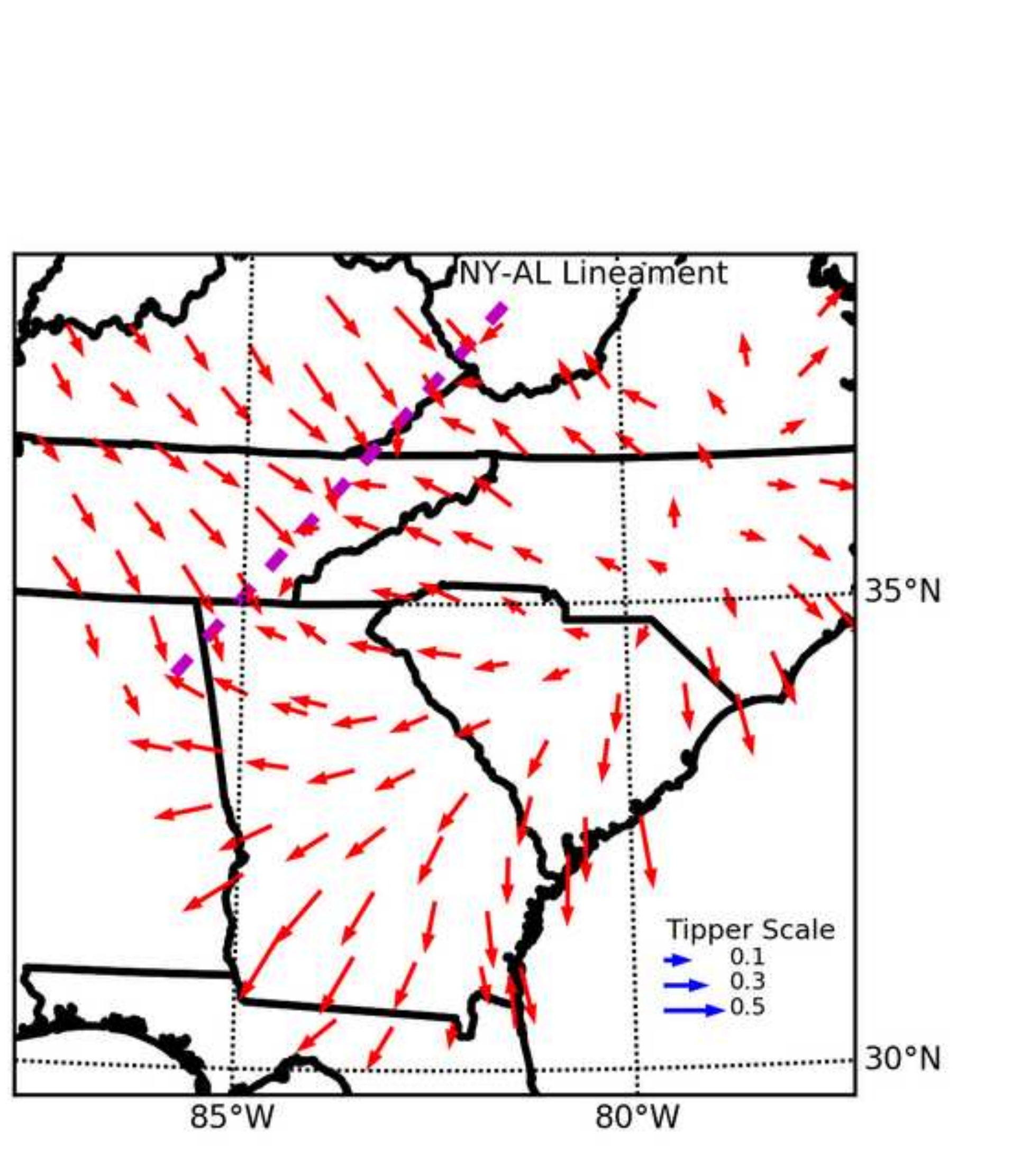


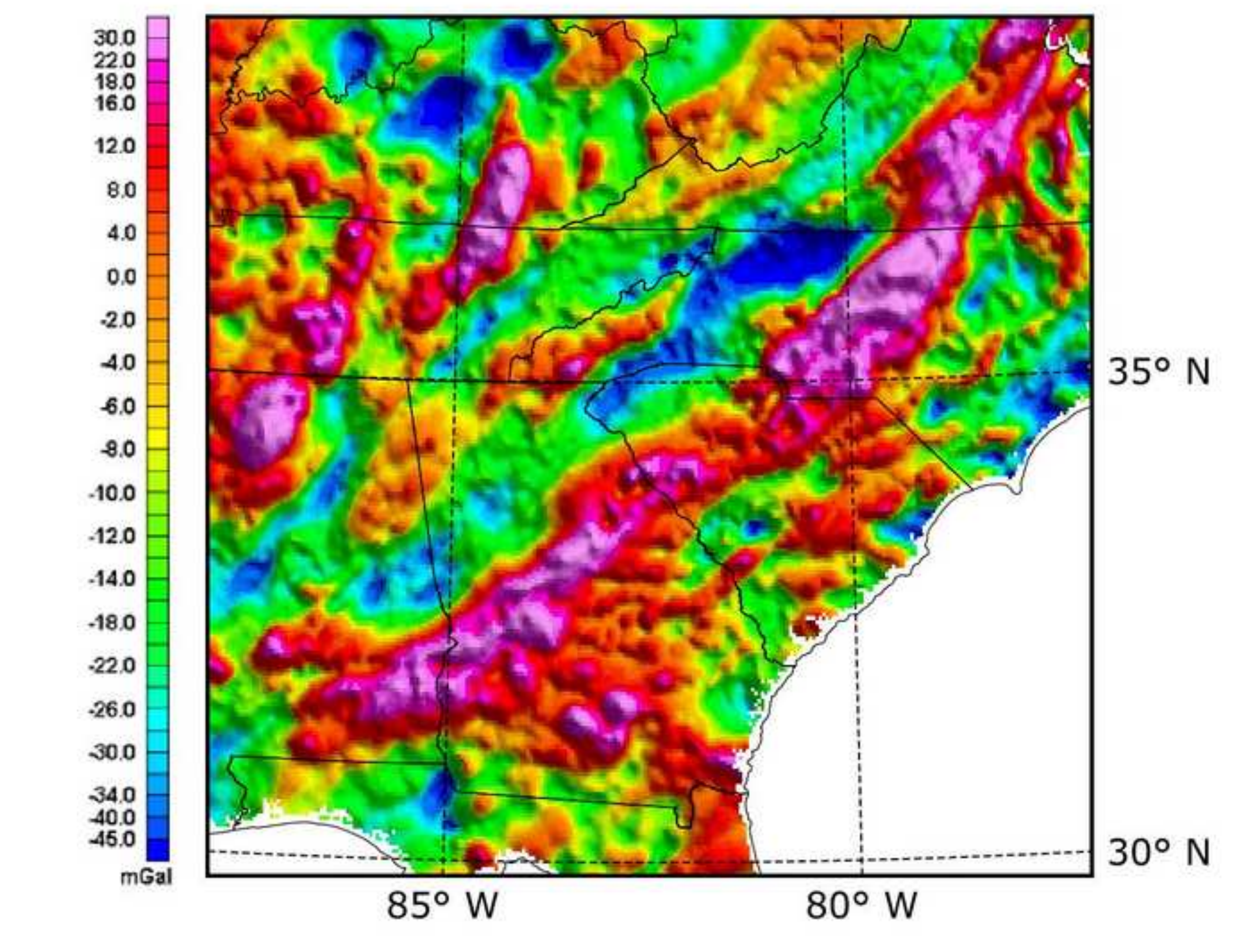

\section{Figure 4}

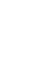
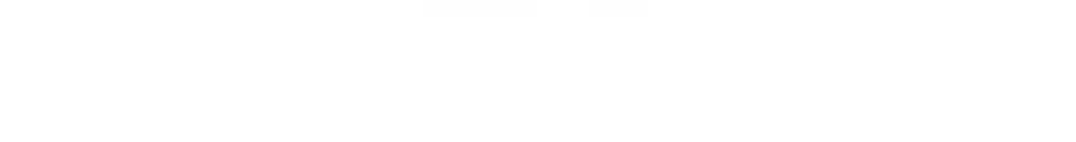

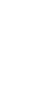




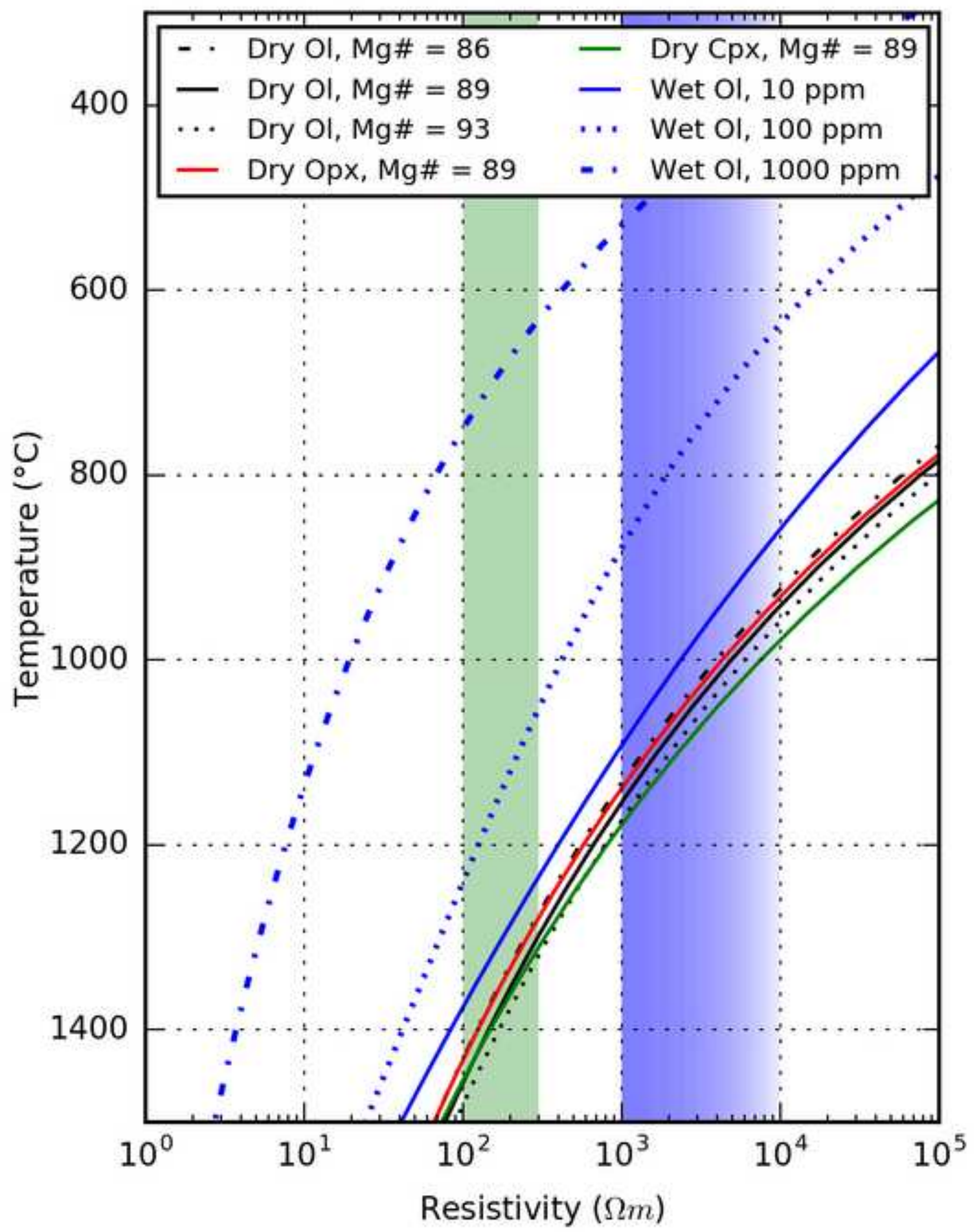


$\sim 230$ Ma: Assembly of Pangea

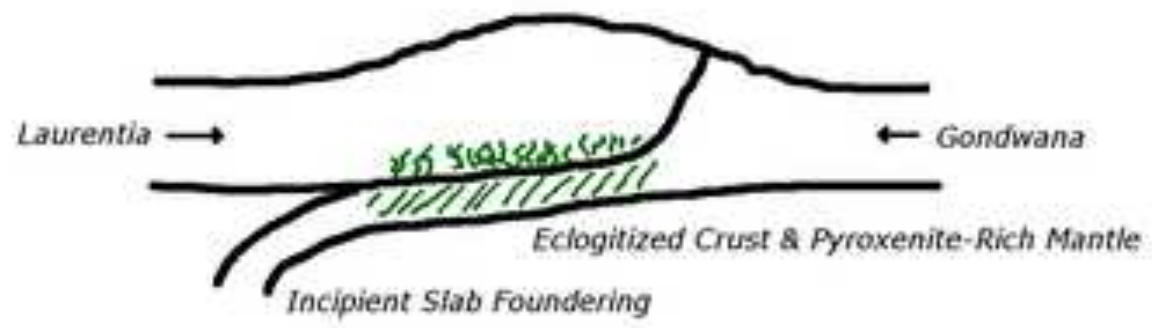

200 Ma: Delamination \& CAMP Magmatism

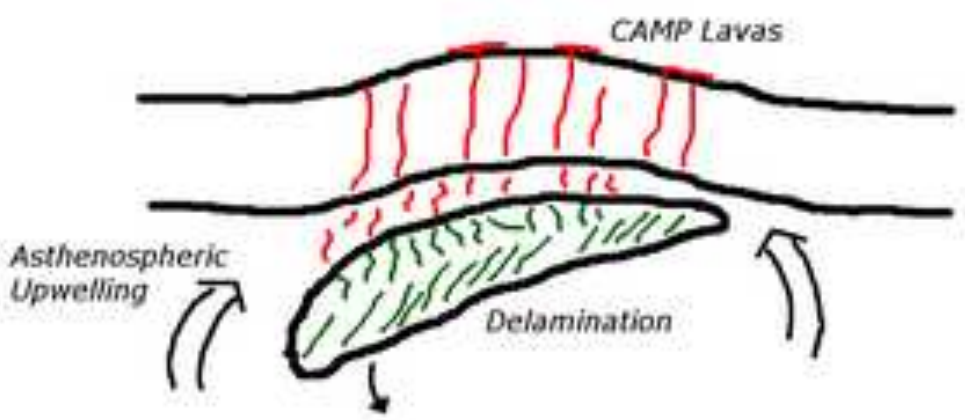

$\sim 190$ Ma: Rifting

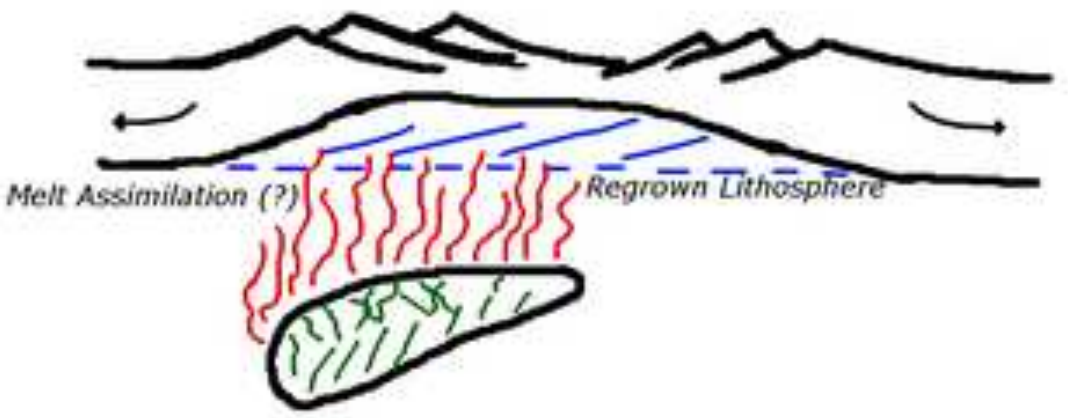

150 Ma: Cooling \& Subsidence

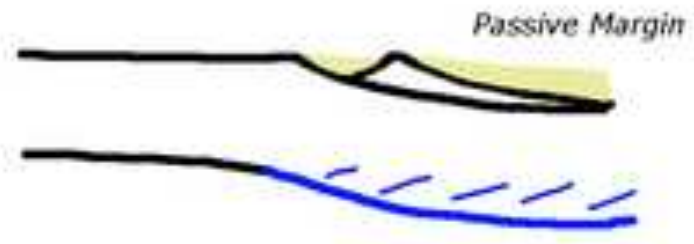

100 Ma - Present: Edge Convection

Topographic

Rejuvenation
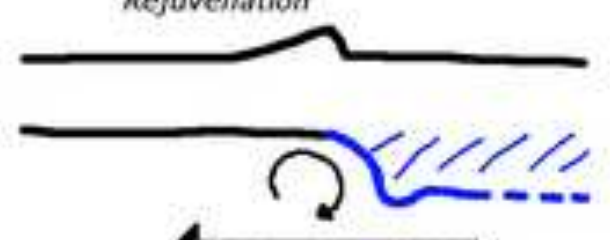

4 Modem Mantle Motion

Modern Appalachians $\longleftrightarrow$ Piedmont 